UDC 621.396.965

DOI: $10.30748 /$ soi.2021.167.02

\author{
V. Dzhus ${ }^{1}$, Y. Roshchupkin ${ }^{1}$, S. Kukobko ${ }^{2}$, S. Herasymov ${ }^{1}$, N. Drob ${ }^{1}$, M. Trofymova $^{1}$ \\ ${ }^{1}$ Ivan Kozhedub Kharkiv National Air Force University, Kharkiv \\ ${ }^{2}$ State Scientific Research Institute of Armament and Military Equipment Testing \\ and Certification, Chernihiv
}

\title{
ESTIMATION OF NOISE RADIANCE POINT SOURCES MULTICHANNEL DIRECTION FINDING SYSTEMS RESOLUTION BY LINEAR PREDICTION METHOD
}

The resolution of multichannel direction finding systems of independent noise radiance point sources is estimated quantitatively under a limited learning sample on the basis of a linear prediction methods "bank" and modified Capon algorithms.

Keywords: linear prediction, methods of spectral estimation, spectral analysis, radar with a phased array, point sources.

\section{Introduction}

Special attention has been given to "super-decisive" methods of spectral estimation [1-15] in the literature of recent years. They include, in particular, methods of linear prediction (LP) and modified Capon algorithms (MAC) with different numbers of the prediction elements [1-3]. The resolution of these methods depends on the number of the prediction element, the optimal value of which usually cannot be set a priori, as it depends on a set of previously unknown parameters [4]. A possible way to maximize the resolution on the basis of these methods is to use their combination ("bank [5]") with different prediction elements numbers. This measure is similar to that previously proposed in [4-5] for a set of intrinsic structural (projection) methods of spectral analysis.

The purpose of the article is to analyze the resolution determining of the independent noise radiance point sources angular coordinates in a radar with a phased array on the basis of LP and MAC methods "bank" in the real conditions of parametric a priori uncertainty and the finite volume learning samples.

\section{Statement of basic materials}

\section{Multichannel direction finding system on the basis of LP and MAC methods "bank"}

The spectral functions (SF) of the LP and MAC methods have the form $[1 ; 6]$ :

$$
\begin{gathered}
\widehat{S}_{L P}(\alpha, i)=\widehat{\omega}_{i i}\left|\mathbf{e}_{i} \hat{\Psi} \mathbf{x}(\alpha)\right|^{2} ; \\
\widehat{S}_{M A C}(\alpha, i)=\widehat{\omega}_{i i}(\mathbf{x}(\alpha) \hat{\Psi} \mathbf{x}(\alpha))\left|\mathbf{e}_{i} \widehat{\Psi} \mathbf{x}(\alpha)\right|^{2} .
\end{gathered}
$$

Where $i \in 1, M$ is the number of the prediction element;

$$
\widehat{\Psi}=\left\{\widehat{\omega}_{g m}\right\}_{g, m=1}^{M}=\widehat{\Phi}^{1}-
$$

the random matrix, which is inverse to the used estimate $\widehat{\Phi}=\left\{\hat{\xi}_{g m}\right\}_{g, m=1}^{M}$ of a priori unknown spatial $M \times M$ correlation matrix (CM) [3]:

$$
\Phi=\left\{\varphi_{g m}\right\}_{g, m=1}^{M}=\overline{\mathbf{y}_{k} \mathbf{y}_{k}},
$$

M-dimensional Gaussian (normal) mutually independent vectors

$$
\begin{gathered}
\mathbf{Y}=\left\{\mathbf{y}_{k}\right\}_{k=1}^{K}, \mathbf{y}_{k}=\left\{y_{m}^{(k)}\right\}_{m=1}^{M} \sim \mathrm{N}_{c}(0, \Phi), \overline{\mathbf{y}}_{k}=0, \\
\overline{\mathbf{y}_{k} \mathbf{y}_{r}}=0, k \neq r
\end{gathered}
$$

the output signals complex amplitudes of the $M$ elemen antenna array (AR) at the $k$ th $(k=1, K)$ discrete moment in time; $\mathbf{e}_{i}-i$ th $(i \in 1, M)$ column of the identity $M \times M$ matrix $\mathrm{I}_{M} ;\left(^{*}\right)$ and the bar above are the symbols of Hermitian conjugation and statistical averaging accordingly, $\mathbf{x}(\alpha)=\left\{x_{m}(\alpha)\right\}_{m=1}^{M}$ is a nonrandom phasing vector (search) in the direction $\alpha$, depending on the geometry of the location and the directivity diagram of the PAR elements.

As (1) and (2) indicate the SF of the LP and MAC methods depend on a parameter $i \in 1, M$ that has the meaning of the PAA element number, which signal is "predicted". LP and MAC methods with different values $i$ have different efficiency in the general case, in particular, resolution.

As an illustration of this, Fig. 1-3 demonstrate examples of normalized SF methods LP (1) (curves 1 and 2) and MAC (2) (curves 3 and 4) for $i=1$ (curves 1 and 3 ) and $i=(M+1) / 2$ ( curves 2 and 4 ) in a hypothetical situation of exactly known CM $\Phi$ (4). These SF are constructed for the test case of two equal-power ( $h_{1}=h_{2}=h$ ) noise radiances generated by independent sources (ES) with a relative angular distance between them

$$
\Delta=\left(\beta_{2} \beta_{1}\right) / \Delta_{0}=0,1, \Delta_{0}=2 \pi / M .
$$

Here $\beta_{n}=2 \pi d \sin \theta_{n} / \lambda \quad(n \in 1,2)$ is the generalized angular direction of the $n$-th ES; $\lambda$ and $d$ - wavelength and pitch of the linear equidistant antenna array (LEAR), respectively; $\theta_{n}-$ is the angle measured from the LEAR normal in the direction to the $n$-th ES; $\Delta_{0}-$ 
half-width of the in-phase directional diagram $M$ element LEAR at the level of the first zeros; $h$ - relative (in relation to the intrinsic noise of the receiving elements) intensities of the ES.

Fig. 1 corresponds to the generalized signal-to-noise ratio (SNR) $q=M h=4000(36 d B)$, Fig. $2-$ to the value $q=400(26 d B)$, Fig. 3 - to the value $q=40(16 d B)$.

As is evidenced by these figures, under conditions of "large" $q=36 d B$ (Fig. 1), each of the SF has two pronounced maxima at points $\alpha=\alpha_{\max }$ in the neighborhood of the true directions on the ES shown by arrows. The methods (1) and (2) SF with the same values of $i$ differ a little from each other under these conditions. Mean element prediction provides sharper SF peaks $\alpha_{\min }$ with less deviations from the directions on the ES and a lower SF value at the minimum point than the extreme prediction. "The depth of a dip" between the SF values at the points $\beta_{n}(n=1.2)$ of the ES true location and at the midpoint

$$
\beta_{\text {midl }}=\left(\beta_{1}+\beta_{2}\right) / 2,
$$

is characterized by the parameter

$$
\gamma=S\left(\beta_{n}\right) / S\left(\beta_{\text {midl }}\right),
$$

and outnumbers the quoted values $10 \mathrm{~dB} \gamma_{0} \approx 2(3 \mathrm{~dB})$, typically for Rayleigh resolution [4-5].

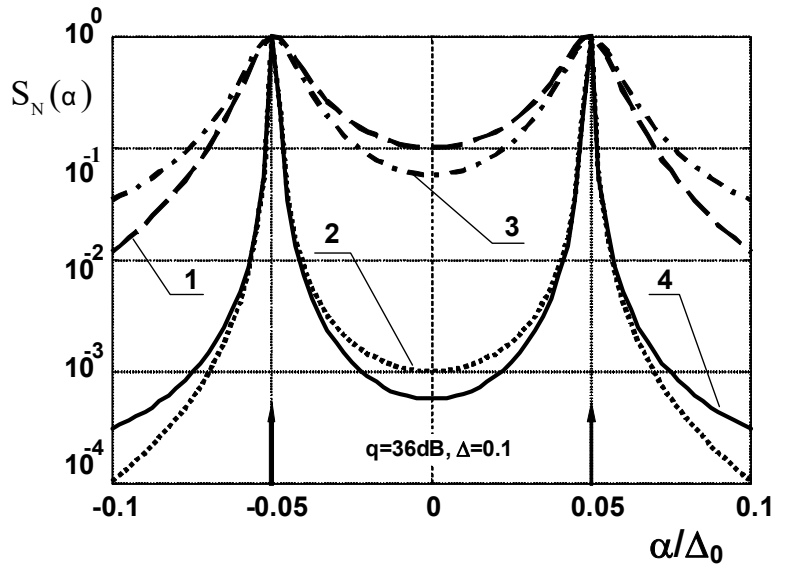

Fig. 1. LP and MAC methods' SF, $q=36 \mathrm{~dB}$ Source: developed by authors.

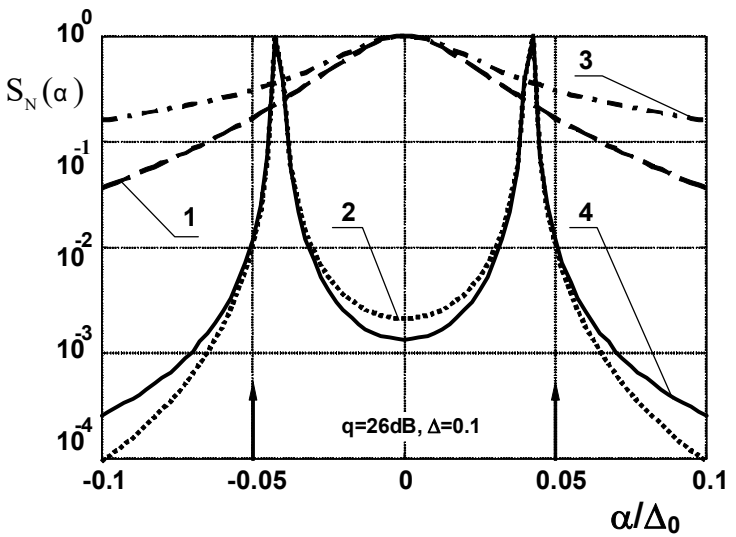

Fig. 2. LP and MAC methods' SF, $q=26 \mathrm{~dB}$ Source: developed by authors.

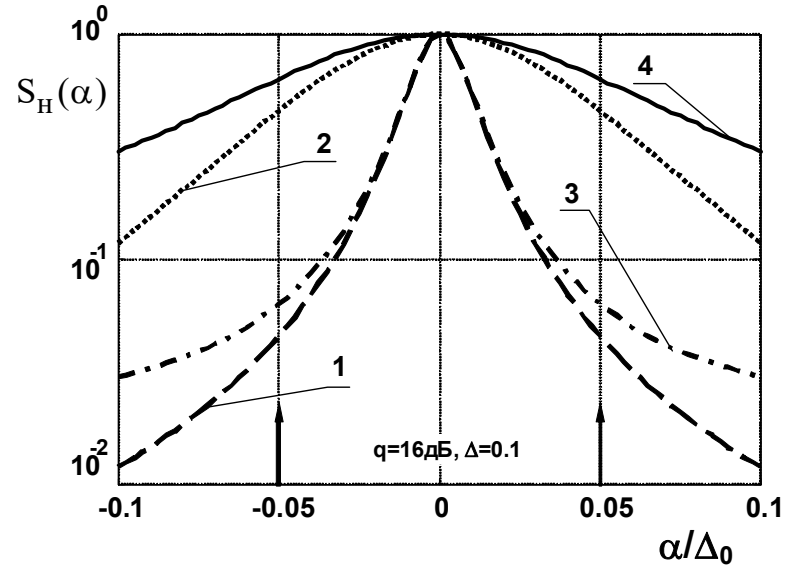

Fig. 3. LP and MAC methods' SF, $q=16 \mathrm{~dB}$ Source: developed by authors.

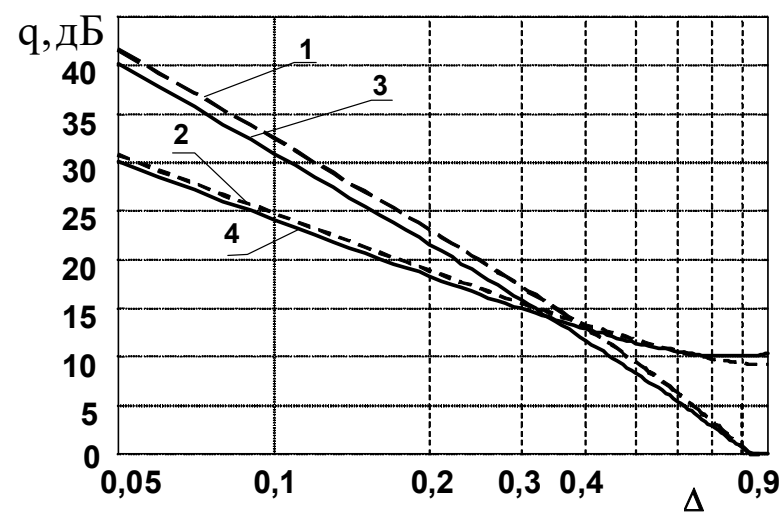

Fig.4. Dependence of SNR $q(\Delta)$ with $\gamma=2$. Source: developed by authors.

As $q$ value is decreased (Fig. 2), there are possible situations when the SF of methods (1), (2) with $i=(M+1) / 2$ remain bimodal with values $\gamma>\gamma_{0}$, that means, they still resolve sources according to Rayleigh's criterion, although they provide a slightly lower accuracy estimates of the angular coordinates. In the role of these coordinates are ones of the corresponding SF maxima, "approaching" in comparison with the conditions of Fig. 1.

At the same time these SF are unimodal with $i=1$, and thereby they do not resolve ES. These unimodal SF have maxima at point $\beta_{m s d l}$ (7), and therefore, the error in measuring the angular coordinate of each $\mathrm{ES}$ is $0,5 \Delta$.

At "low" intensities ( $q=16 d B$, Fig. 3), the SF methods (1) and (2) for any $i(i \in 1, M)$ have a single maximum at the point $\alpha=\beta_{\text {midl }}$, so that $\gamma<\gamma_{0}$ and the ES are not resolved, and the measurement errors are $0,5 \Delta$.

Fig. 4 shows the dependence of SNR $q$ on the relative angular distance $\Delta(6)$ between two equal-power ES, at which the parameter of "the dip depth" (7) in the SF (1), (2) under LEAR conditions is equal to $\gamma=\gamma_{0}=2$ [1-3]. The designations of the curves coincide here with the designations of Fig.1-3. It can be seen that the choice 
of the middle prediction element $(i=(M+1) / 2, M-$ odd) provides a higher resolution according to the criterion (7) than the choice of the extreme one $(i=1)$, up to values $\Delta \leq 0,35$.

When we use various random matrix-estimates of $\widehat{\Phi}$ instead of an a priori unknown true CM $\Phi$ (4) in real conditions, SF (1), (2) are also random, and, therefore, similar (8) resolution conditions are fulfilled only with one or another probability. That is why the conclusions about the comparative merits of various methods arising from Fig. 1-4, corresponding to the hypothetical conditions of exact CM may actually be false, and the choice of the prediction element number based on Fig. 4 may be unreasonable.

It is suitable to switch to a multichannel direction finding system of ES [5] based on a rational strategy of spectral analysis (SA) methods set ("bank") using under these conditions.

This article focuses on the comparative analysis of "banks" of LP and MAC methods with different numbers of prediction elements at a learning sample (5) of a limited volume $K$.

This analysis should be based on statistical characteristics (probabilities of correct resolution and confidence intervals for assessing the ES angular positions) of the used "banks" in connection with the mentioned randomness. However, their analytical search encounters serious mathematical difficulties, therefore it is carried out by the method of mathematical modeling in this work.

\section{Methods of mathematical modeling and its results statistical processing}

The purpose of mathematical modeling is to determine the dependences of the ES $P_{5}$ correct resolution probability of the SA methods relevant "banks" on the learning sample volume. These probabilities are found by statistical processing of the results obtained in a series of $G>>1$ tests. It is provided for determining the true CM $\Phi$ (4) a given headlight geometry, number, spatial location and power of the ES in each of these tests:

calculation of the "root" of the true CM $\Phi$ (4), i.e. matrix $\Phi^{1 / 2}$ satisfying the condition

$$
\Phi^{1 / 2}\left(\Phi^{1 / 2}\right)=\Phi
$$

formation of $K \geq M$-dimensional learning sample Y (5) according to the ratio [1]:

$$
\mathbf{Y}=\left\{\mathbf{y}_{k}\right\}_{k=1}^{K}=\boldsymbol{\Phi}^{1 / 2} \xi
$$

where $\xi=\left\{\xi_{k}\right\}_{k=1}^{K}-M \times K$ matrix, whose columns are $M$ dimensional Gaussian mutually independent from each other

$$
\xi_{k}=\left\{\xi_{m}^{(k)}\right\}_{m=1}^{M} \sim N_{c}\left(0, I_{M}\right) ; \overline{\xi_{k}}=0 ;
$$

$$
\overline{\xi_{k} \xi_{r}}=0 ; k \neq r
$$

with independent elements formed by standard random number generators;

calculation of estimated KM

$$
\widehat{\Phi}=\mathbf{Y Y} / K, \quad K M=\delta \geq 0 ;
$$

under conditions (5), which is the maximum likelihood (MP) estimate of the CM $\Phi$ (4);

determining the values of random SF (1), (2) on the analysis interval $\alpha_{a} \in\left[\alpha_{\text {begin }}, \alpha_{\text {end }}\right]$ for different numbers of prediction elements $i \in 1, M$;

searching for each of them the coordinates $\alpha_{n}$ ( $n \in 1, \widehat{N}) \hat{N}$ of the main maxima, i.e. those in which the conditions are hold

$$
\widehat{S}\left(\alpha_{n}\right) / \widehat{S}\left(\eta_{n 1}\right) \geq \gamma_{0}, \widehat{S}\left(\alpha_{n}\right) / \widehat{S}\left(\eta_{n}\right) \geq \gamma_{0},
$$

where, $\alpha_{n} \in \alpha_{a}(n \in 1, \widehat{N})$ are the ascending (ranked) coordinates of the SF maxima, $\eta_{n} \in \alpha_{a},(n \in 0, \widehat{N})$ are the coordinates $\widehat{N}+1$ of the ranked SF minimum values.

The ranked sets $\alpha_{n}(n \in 1, \hat{N})$ obtained for each method of the entire series from $G>>1$ tests are statistically processed then to determine the desired probabilities of methods (1), (2) correct resolution, "banks" based on them.

Processing includes:

determination of the ES correct resolution probability $P_{i}$ by LP and MAC methods for all $i \in 1, M$. This probability is calculated using the formula

$$
P_{i}=s_{i} / G \text {, }
$$

where $s_{i}$ is the number of trials where the estimate $\widehat{N}_{i}$ of the number of ES by the $i$-th "bank" method coincided with their true number $N$. The maximum value $\widehat{N}_{i}$ $\left(\widehat{N}_{B}=\max \hat{N}_{i}, i \in 1, M\right)$ is taken as an estimate $\hat{N}_{B}$ of the ES number by the "bank";

determination of the probability $P_{B}$ of correct resolution by the corresponding "bank". The same formula (14) is used for this, but $s_{i}$ is the number of tests $s_{B}$, where the $\hat{N}_{B}$ value coincides with $N$.

\section{Mathematical modeling results and their analysis}

The results of mathematical modeling are shown in Fig. 5-7*); modelling was carried out in a test situation of two $(N=2)$ equally powerful $\left(q_{1}=q_{2}=q\right)$ ES with a relative angular distance $\Delta=0.1$ for various values of $q$, which were obtained in a series of $G=500$ tests in $M=17$ - element LEAR. These figures show the dependences of the correct resolution probability (Fig. 5-7) on the effective volume of the methods (1), (2) learning sample $\delta=K M$ (12) and "banks" based on them; these were 
obtained by the item 3 method at the relative intensity of ES $q=36 d B \quad$ (Fig. 5), $q=26 d B \quad$ (Fig. 6) and $q=16 d B$ (Fig. 7) and the choice of the threshold $\gamma_{0}=2(3 d B)$ in (13).

Fig. 5-7 show families of thin solid lines corresponding to SF (1), (2) with different values $i \in 1, M$. Dot-and-dash curve 1 corresponds to the LP and MAC methods "bank" with prediction of only extreme $(i=1)$ and average $(i=(M+1) / 2)$ elements.

In all Fig. 5-7 the dashed curves correspond to the bank of LP methods with prediction of all $(i \in 1, M)$ elements; solid bold curves conform to the "bank" of MAC with $i \in 1, M$; the curves marked with dots correspond to the combination of "banks" of LP and MAC with $i \in 1, M$ methods. These curves are numbered 2, 3 and 4 respectively in Fig. 5-7.

The following conclusions can be drawn from Fig. 5-7.

1. "Bank" even of a small volume (curve 1) provides a higher probability of resolution than each of the methods provides it separately.

2. The enlargement of the "bank" volume (curves 2, 3) provides a further increase of the correct resolution probability. The physical mechanism of this is similar to the mechanism of target-destruction probability increasing due to shots raising.

3. With other things being equal, the higher is the correct resolution probability of every methods and the "banks" based on them, the higher is the ES intensity ( $q$ value).

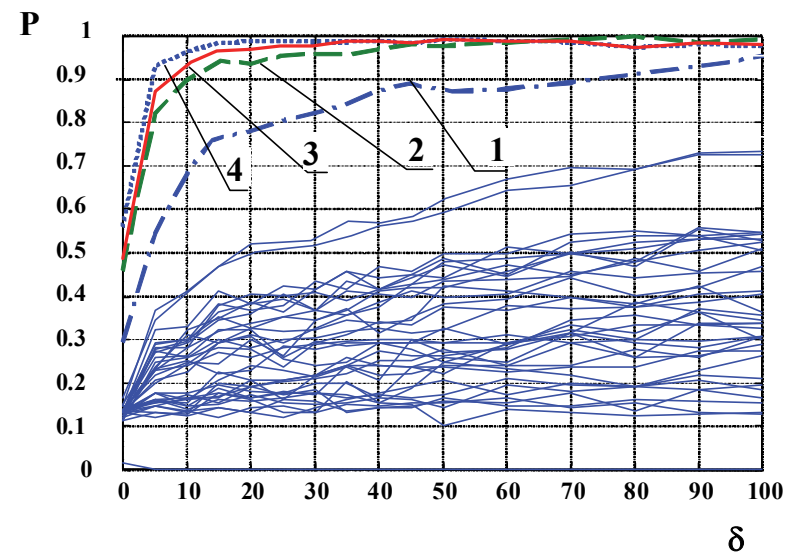

Fig. 5. Dependences of the probability of correct resolution $P$ on the effective volume $\delta$ of the learning sample of LP, MAC and "banks" methods based on them $q=36 \mathrm{~dB}$

Source: developed by authors.

In this regard, the enlargement of the learning sample $\delta$ effective volume increases the coordinates resolution under the conditions of Figs. 5 and 8, when the $q$ values are not less than those required for resolution under the conditions of exact CM in Fig. 1-4. Other case, the enlargement of the sample size may either not increase the processing efficiency or even decrease it
(Fig. 6-7). In particular, the $\delta$ increase decreases the source resolution probability for "small" $q=16 \mathrm{~dB}$ (Fig. 7) when the true SF of all the considered methods are unimodal (Fig. 3), and the estimates of the angular coordinates are grouped in the direction $\beta_{\text {midl }}(7)$, so that the measurement errors tend to the value $0.5 \Delta$.

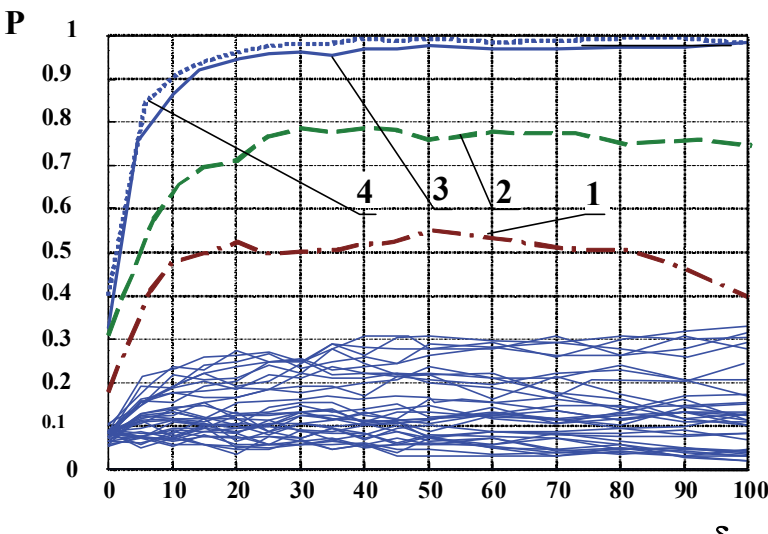

$\delta$

Fig. 6. Dependences of the probability of correct resolution $P$ on the effective volume $\delta$ of the learning sample of LP, MAC and "banks" methods based on them $q=26 \mathrm{~dB}$ Source: developed by authors.

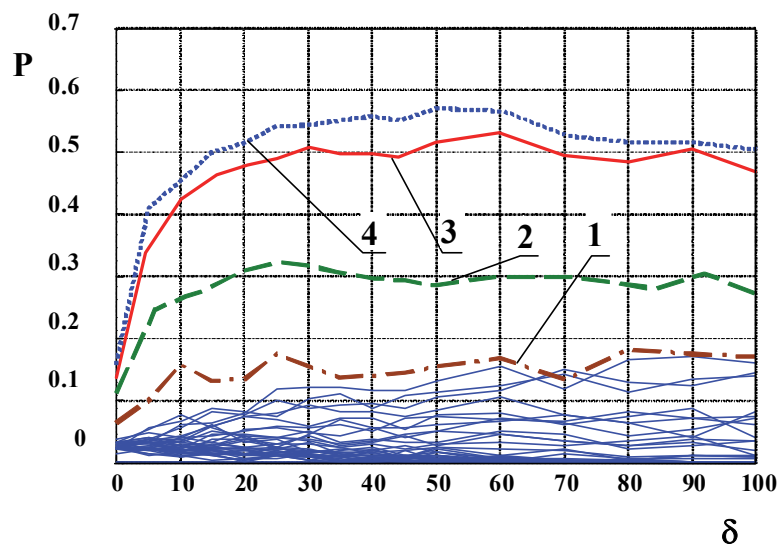

Fig. 7. Dependences of the probability of correct resolution $P$ on the effective volume $\delta$ of the learning sample of LP, MAC and "banks" methods based on them $q=16$ Source: developed by authors.

4. "MAC-bank" (curve 3) makes a decisive contribution to the resolution of the general "LP-MAC-bank" (curve 4, Fig. 5-7). The reasons of the "MAC-Bank" advantages are analyzed in detail in [3]. They are connected with the fact that the SF $S_{L P}(\alpha, i)$ of LP methods is the product of SF $S_{M A C}(\alpha, i)$ and SF $S_{M D}(\alpha)$ of the minimum variance (Capon) method $[1 ; 5-6]$. The latter can be unimodal even in conditions when the SF $S_{M A C}(\alpha, i)$ has extrema in the vicinity of the ES true location. Its "sharpening" effect explains the lower resolving power of LP methods in comparing with MAC. 


\section{Conclusion}

A promising means to increase the direction finding efficiency of pinpoint ES in a phased-array radar is to combine the various SA methods operating results, in particular, to combine LP and MAC methods having a choice of various prediction elements united by a common "bank", and an increase in the number of methods included in the "bank".
It is important to note that the implementation of the LP and MAC methods "bank" can be provided without significant hardware and computational costs if adaptive lattice filters (ALF) [16-17] are used to form the corresponding "bank" [5-6]. It is planned to devote a separate publication to the synthesis and analysis of the features of the corresponding multichannel direction finding system based on the ALF.

\section{References}

1. Shyrman, Ya.D. (2007), "Radioelektronnye Sistemy. Osnovy Postroeniya i Teoriya: spravochnsk" [Radioelectronic Systems. Basics of Construction and Theory: Reference], Radiotehnika, Moscow, Russia, 512 p.

2. Lekhovytskiy, D.I., Riabukha, V.P., Semeniaka, A.V., Atamanskiy, D.V. and Katiushyn, Y.A. (2019), Protection of coherent pulse radars against combined interferences. 1. Modifications of STSP systems and their ultimate performance capabilities, $R a-$ dioelectronics and Communications Systems, Vol. 62, No. 7, pp. 311-341. https://doi.org/10.3103/S073527271907001X.

3. Gershman, A.B. and Bohme, J.F. (1997), Improved DOA estimation via pseudo random resampling of spatial spectrum, IEEE Signal Processing Letters, Vol. 4, pp. 54-57.

4. Lekhovytskiy, D.I., Atamanskiy, D.V. and Djus, V.V. (2005), Combined Direction Finders of DOT Noise Radiation Sources in PAA Based on Adaptive Lattice Filters, V International Conference on Antenna Theory and Techniques (ICATT'05), May 24-27, Kyiv, Ukraine, pp. 95-98. https://doi.org/10.1109/ICATT.2005.1496865.

5. Lekhovytskiy, D.I., Atamanskiy, D.V. and Dzhus, V.V. (2005), "Kombinirovannye pelengatory istochnikov shumovyh izluchenij na osnove adaptivnyh reshetchastyh filtrov" [Combined Direction Finders of Noise Radiation Sources Based on Adaptive Lattice Filters], 2nd International Radio Electronic Forum (IREF'2005) Proceeding, International Conference "Navigation and Location Systems (INLS'2005)”, Vol. II. September 19-23, Kharkov, Ukraine, pp. 246-250.

6. Lekhovitsky, D.I., Shifrin, Y.S., and Atamansky, D.V. (2013), Rapidlu convergent "superresolving" direction fiders of noise radiation sources in adaptive arrays, IX International Conference on Antenna Theory and Techniques, September 16-20, Odessa, Ukraine, pp. 28-34.

7. Herasimov, S., Kozhushko, H., Roshchupkin, Y., Dekadin, V. and Djus, V. (2020), Evaluation of surface profile of holographic diffraction reflective coatings on scattering chart using in laser alarm systems, International Journal of Emerging Trends in Engineering Research, Vol. 8, No. 8, pp. 4502-4507. https://doi.org/10.30534/ijeter/2020/74882020.

8. Lekhovytskiy, D.I., Semeniaka, A.V. and Rachkov, D.S. (2017), Statistical analysis of accuracy estimation of the continuous energy spectra in pulse Doppler weather radars, 18th International Radar Symposium (IRS), June 28-30, Prague, Czech Republic, pp. 1-9. https://doi.org/10.23919/IRS.2017.8008175.

9. Riabukha, V.P., Lekhovytskiy, D.I., Semeniaka, A.V. and Katiushyn, Y.A. (2017), An exploratory model of the hardwaresoftware unit for adaptive digital time signal processing against the background of masking clutters, IEEE First Ukraine Conference on Electrical and Computer Engineering (UKRCON), May 28-30, Prague, Czech Republic, pp. 55-58. https://doi.org/10.1109/UKRCON.2017.8100458.

10. Riabukha, V.P., Lekhovytskiy, D.I., Katiushyn, Y.A. and Semeniaka, A.V. (2017), Choice of number, structure and placement of compensation modules in the radar with planar PAA, XI International Conference on Antenna Theory and Techniques (ICATT2017), May 24-27, Kyiv, Ukrane, pp. 197-198. https://doi.org/10.1109/ICATT.2017.7972620.

11. Lekhovytskiy, D.I. (2016), To the theory of adaptive signal processing in systems with centrally symmetric receive channels, EURASIP Journal on Advances in Signal Processing, Vol. 33, No. 1, pp. 1-11. https://doi.org/10.1186/s13634-016-0329-z.

12. Lekhovytskiy, D.I., Atamanskiy, D.V., Rachkov, D.S. and Semeniaka, A.V. (2015), Improvement of accuracy of meteorological objects velocity unambiguous measurement in Doppler weather radars with staggered pulse repetition times, Radioelectronics and Communications Systems, Vol. 58, No. 9, pp. 385-403. https://doi.org/10.3103/S0735272715090010.

13. Lekhovytskiy, D.I. (2018), Adaptive lattice filters for systems of space-time processing of non-stationary Gaussian processes, Radioelectronics and Communications Systems, Vol. 61, No. 11, pp. 477-514. https://doi.org/10.3103/S0735272718110018.

14. Herasimov, S., Roshchupkin, E., Kutsenko, V., Riazantsev, S. and Nastishin, Yu. (2020), Statistical analysis of harmonic signals for testing of Electronic Devices, International Journal of Emerging Trends in Engineering Research, No. 8(7), pp. 3791-3798. https://doi.org/10.30534/ijeter/2020/143872020.

15. Herasimov, S., Borysenko, M., Roshchupkin, E., Hrabchak, V. and Nastishin, Yu. (2021), Spectrum Analyzer Based on a Dynamic Filter, Journal of Electronic Testing: Theory and Application, Vol. 37, pp. 357-368. https://doi.org/10.1007/s10836-02105954-0.

16. Lekhovytskiy, D.I., Atamanskiy, D.V., Rachkov, D.S. and Semeniaka, A.V. (2015), Estimation of the energy spectrums of reflections in pulse Doppler weather radars. Part 1. Modifications of the spectral estimation algorithms, Radioelectronics and Communications Systems, Vol. 58, No. 12, pp. 523-550. https://doi.org/10.3103/S0735272715120018.

17. Lekhovytskiy, D.I., Riabukha, V.P., Rachkov, D.S. and Semeniaka, A.V. (2016), "Rekurrentnye alghorytmy nastrojky adaptyvnykh reshetchatykh fyljtrov" [Recursive algorithms of adaptive lattice filters adjustment], Tehnologiya $i$ Konstruirovanie $v$ Elektronnoi Apparature, Vol. 2, No. 3, pp. 26-32. http://dx.doi.org/10.15222/TKEA2016.2-3.26.

\section{Список літератури}

1. Ширман Я. Д. Радиоэлектронные системы. Основы построения и теория: справочник. Москва :Радиотехника, 2007. $512 \mathrm{c}$.

2. Lekhovytskiy D. I., Riabukha V. P., Semeniaka A. V., Atamanskiy D. V., Katiushyn Y.A., Protection of coherent pulse radars against combined interferences. 1. Modifications of STSP systems and their ultimate performance capabilities. Radioelectronics 
and Communications Systems. 2019. Vol. 62. No. 7. P. 311-341. https://doi.org/10.3103/S073527271907001X.

3. Gershman A. B., Bohme J. F. Improved DOA estimation via pseudo random resampling of spatial spectrum. IEEE Signal Processing Letters. 1997. Vol. 4. P. 54-57.

4. Lekhovytskiy D. I., Atamanskiy D. V., Djus V.V. Combined Direction Finders of DOT Noise Radiation Sources in PAA Based on Adaptive Lattice Filters, V International Conference on Antenna Theory and Techniques (ICATT'05), May 24-27, 2005. Kyiv, 2005. P. 95-98. https://doi.org/10.1109/ICATT.2005.1496865.

5. Леховицкий Д. И., Атаманский Д. В., Джус В. В. Комбинированные пеленгаторы источников шумовых излучений на основе адаптивных решетчастых фильтров. 2 Международный радиоэлектронный форум "Прикладная радиоэлектроника. Состояние и перспективы развития” (МРФ'2005) : сборник научных трудов. Том II. 19-23 сентября 2005. Харьков. C. 246-250.

6. Lekhovitsky D. I., Shifrin Y. S., Atamansky D. V. Rapidlu convergent "superresolving” direction fiders of noise radiation sources in adaptive arrays. IX Международная конференция по теории и технике антенн (IСАТT'13) : сборник тезисов, Одесса, 16-20 сентября 2013. Одесса, 2013. С. 28-34.

7. Herasimov S., Kozhushko H., Roshchupkin Y., Dekadin V., Djus V. Evaluation of surface profile of holographic diffraction reflective coatings on scattering chart using in laser alarm systems. International Journal of Emerging Trends in Engineering Research. 2020. Vol. 8. No. 8. P. 4502-4507. https://doi.org/10.30534/ijeter/2020/74882020.

8. Lekhovytskiy D. I., Semeniaka A. V., Rachkov D. S. Statistical analysis of accuracy estimation of the continuous energy spectra in pulse Doppler weather radars. 18th International Radar Symposium (IRS). Prague, June 28-30, 2017. Prague, 2017. P. 1-9. https://doi.org/10.23919/IRS.2017.8008175.

9. Riabukha V. P., Lekhovytskiy D. I., Semeniaka A. V., Katiushyn Y. A. An exploratory model of the hardware-software unit for adaptive digital time signal processing against the background of masking clutters. IEEE First Ukraine Conference on Electrical and Computer Engineering (UKRCON). Prague, May 28-30, 2017. Prague, 2017. P. 55-58. https://doi.org/10.1109/UKRCON.2017.8100458.

10. Riabukha V. P., Lekhovytskiy D. I., Katiushyn Y. A., Semeniaka A. V. Choice of number, structure and placement of compensation modules in the radar with planar PAA. XI International Conference on Antenna Theory and Techniques (ICATT2017), May 24-27, 2017. Kyiv, 2017. P. 197-198. https://doi.org/10.1109/ICATT.2017.7972620.

11. Lekhovytskiy D. I. To the theory of adaptive signal processing in systems with centrally symmetric receive channels. EURASIP Journal on Advances in Signal Processing. 2016. Vol. 33. No. 1. P. 1-11. https://doi.org/10.1186/s13634-016-0329-z.

12. Lekhovytskiy D. I., Atamanskiy D. V., Rachkov D. S., Semeniaka A. V. Improvement of accuracy of meteorological objects velocity unambiguous measurement in Doppler weather radars with staggered pulse repetition times. Radioelectronics and Communications Systems. 2015. Vol. 58. No. 9. P. 385-403. https://doi.org/10.3103/S0735272715090010.

13. Lekhovytskiy D. I. Adaptive lattice filters for systems of space-time processing of non-stationary Gaussian processes. $R a$ dioelectronics and Communications Systems. 2018. Vol. 61. No. 11. pp. 477-514.https://doi.org/10.3103/S0735272718110018.

14. Herasimov S., Roshchupkin E., Kutsenko V., Riazantsev S., Nastishin Yu. Statistical analysis of harmonic signals for testing of Electronic Devices. International Journal of Emerging Trends in Engineering Research. 2020. No. 8(7). P. $3791-3798$. https://doi.org/10.30534/ijeter/2020/143872020.

15. Herasimov S., Borysenko M., Roshchupkin E., Hrabchak V., Nastishin Yu. Spectrum Analyzer Based on a Dynamic Filter. Journal of Electronic Testing: Theory and Application. 2021. Vol. 37. P. 357-368. https://doi.org/10.1007/s10836-021-05954-0.

16. Lekhovytskiy D. I., Atamanskiy D. V., Rachkov D. S., Semeniaka A. V. Estimation of the energy spectrums of reflections in pulse Doppler weather radars. Part 1. Modifications of the spectral estimation algorithms. Radioelectronics and Communications Systems. 2015. Vol. 58. No. 12. P. 523-550. https://doi.org/10.3103/S0735272715120018.

17. Леховицкий Д. И., Рябуха В. П., Рачков Д. С., Семеняка А. В. Рекуррентные алгоритмы настройки адаптивных решетчатых фильтров. Технология и конструирование в электронной аппаратуре. 2016. Вып. 2. № 3. С. 26-32. http://dx.doi.org/10.15222/TKEA2016.2-3.26.

\section{Вidомості про авторів:}

Джус Володимир Всеволодович кандидат технічних наук доцент провідний науковий співробітник Харківського національного університету

Повітряних Сил ім. І. Кожедуба,

Харків, Україна

https://orcid.org/0000-0003-1762-1543

\section{Рощупкін Свгеній Сергійович}

кандидат технічних наук старший науковий співробітник старший викладач

Харківського національного університету

Повітряних Сил ім. І. Кожедуба,

Харків, Україна

https://orcid.org/0000-0003-1089-9681

\section{Information about the authors:}

Volodymyr Dzhus

$\mathrm{PhD}$ in Engeneering Associate Professor

Leading Researcher

of Ivan Kozhedub Kharkiv National

Air Force University,

Kharkiv, Ukraine

https://orcid.org/0000-0003-1762-1543

\section{Evgeniy Roshchupkin}

$\mathrm{PhD}$ in Engeneering Senior Researcher

Senior Lecturer

of Ivan Kozhedub Kharkiv National

Air Force University,

Kharkiv, Ukraine

https://orcid.org/0000-0003-1089-9681 


\section{Кукобко Сергій Вікторович}

кандидат технічних наук старший науковий співробітник начальник науково-дослідного відділу

Державного науково-дослідного інституту випробувань і сертіфікації озброєння та військової техніки,

Чернігів, Україна

https://orcid.org/0000-0001-6289-4458

Герасимов Сергій Вікторович

доктор технічних наук професор

Харківського національного університету

Повітряних Сил ім. І. Кожедуба,

Харків, Україна

https://orcid.org/0000-0003-1810-0387

Дроб Наталія Чеславівна

старший науковий співробітник

Харківського національного університету

Повітряних Сил ім. І. Кожедуба,

Харків, Україна

https://orcid.org/0000-0002-9849-2976

Трофимова Марина Леонідівна

молодший науковий співробітник

Харківського національного університету

Повітряних Сил ім. І. Кожедуба,

Харків, Україна

https://orcid.org/0000-0003-4466-168X

\section{Sergey Kukobko}

$\mathrm{PhD}$ in Engeneering Senior Researcher

Head of Scientific Research Department

of State Scientific Research Institute of Armament

and Military Equipment Testing and Certification,

Chernigiv, Ukraine

https://orcid.org/0000-0001-6289-4458

\section{Sergey Herasimov}

Doctor of Engeneering Science Professor

of Ivan Kozhedub Kharkiv National

Air Force University,

Kharkiv, Ukraine

https://orcid.org/0000-0003-1810-0387

Natalia Drob

Senior Researcher

of Ivan Kozhedub Kharkiv National

Air Force University,

Kharkiv, Ukraine

https://orcid.org/0000-0002-9849-2976

\author{
Maryna Trofymova \\ Junior Researcher \\ of Ivan Kozhedub Kharkiv National \\ Air Force University, \\ Kharkiv, Ukraine \\ https://orcid.org/0000-0003-4466-168X
}

\title{
ОЦІНКА РОЗДІЛЬНОЇ ЗДАТНОСТІ БАГАТОКАНАЛЬНИХ СИСТЕМ ПЕЛЕНГАЦІЇ ТОЧКОВИХ ДЖЕРЕЛ ШУМОВИХ ВИПРОМІНЮВАНЬ МЕТОДОМ ЛІНІЙНОГО ПЕРЕДБАЧЕННЯ
}

\author{
В.В. Джус, С.С. Рощупкін, С.В. Кукобко, С.В. Герасимов, Н.Ч. Дроб, М.Л. Трофимова
}

У сучасній науковій літературі багато уваги приділяється надрозділяючим методам спектрального аналізу, безпосередньо методам лінійного передбачення (ЛП) та модіфікованим алгоритмам Кейпона (МАК). Роздільна здатність таких методів залежить від номера елемента передбачення, оптимальне значення якого апріорі не відомо. Можливий спосіб максимізації роздільної здатності грунтується на сукупному застосуванні сукупності таких методів з різними номерами елементів передбачення. Метою статті є аналіз роздільної здатності визначення кутових координат точкових джерел шумових випромінювань (ДШВ) у радіолокаторах з ФАР на основі банка методів ЛП та МАК у реальних умовах параметричної апріорної невизначенності та обмеженого об' єму вибірки прийнятого сигналу.

У статті описано поряд формування спектральних функцій методів ЛП та МАК у залежності від номера елемента передбачення. Наведені спектральні функиї цих методів, побудовані по точним кореляційним матрииям прийнятих коливань. Показано, щзо в залежності від потужності та кутової відстані джерел спектральні функиії мають один або два максимуми, яки визначають потениійну роздільну здатність иих методів за критерієм Релея. Приведені залежності відношення сигнал - шум від відносного кутового розузгодження між двома рівнопотужними ДШВ, при яких глибина провалу забезпечує роздільне спостереження иих джерел. Показано, що в умовах застосування точно відомої кореляиійної матричі вищу роздільну здатність забезпечує вибор середнього елемента передбачення, ніж крайнього. При матиматичному моделюванні визначалась залежність імовірності правільного розділення ДШВ методів, що розглядаються, від об'єму прийнятої вибірки. Ці імовірності отримуються шляяом статистичної обробки результатів, получених в серії з 500 випробувань. В кожному з них для визначеної геометрї ФАР, кількості, просторового розположення та потужності ДШВ, визначалась істинна кореляиійна матриия прийнятих сигналів на вході ФАР. Далі визначалися корні иієї матриці, на основі одного з них формувалась вибірка прийнятого сигналу визначеного об'єму. За допомогою иієї вибірки розраховувалась оцінка кореляційної матриці, остання застосовувалась для побудови у визначених межах спектральних функиій методів ЛП та МАК з різними номерами. Для кожної з таких функиій визначалась кількість максимумів у відповідності до обраного критерія. Отримані результати статистично оброблялись для визначення імовірності правільного розділення кожного методу окремо та у иілому для банку методів на основі ицх методів. За результатами моделювання отримані таки висновки: банк малого об'єму методів забезпечує більш високу роздільну здатність, ніж кожного метода окремо; збільшення об'єму банка методів забезпечує подальше збільшення роздільної здатності пеленгатору; за рівних умов імовірність правільного розділення як кожного методу, так $i$ банка $у$ цілому на їх основі вищче при збільшенні інтенсивності ДШВ; визначальний вклад у роздільну здатність загального банку методів вносить група методів МАК. Перспективним шляхом підвищення ефективності пеленгації точкових ДШВ в радіолокаторах з ФАР є комбінування результатів роботи різних методів спектрального аналізу, зокрема методів ЛП та МАК з вибором різних номерів елементів передбачення, які об'єднані загальним банком. 3 ростом кількості методів у банку збільшується роздільна здатність радіолокатору. Реалізачія такого банка методів спектрального аналізу реалізується без значних обчислювальних витрат, якщо для формування такого банку застосовуються адаптивні решитчасті фільтр.

Ключові слова: лінійне передбачення, методи спектрального оцінювання, спектральний аналіз,радіолокатор з фазованою антенною решиткою, точкові джерела випромінювання. 
ОЦЕНКА РАЗДЕЛЬНОЙ СПОСОБНОСТИ МНОГОКАНАЛЬНЫХ СИСТЕМ ПЕЛЕНГАЦИИ ТОЧЕЧНЫХ ИСТОЧНИКОВ ШУМОВЫХ ИЗЛУЧЕНИЙ МЕТОДОМ ЛИНЕЙНОГО ПРЕДВИДЕНИЯ

В.В. Джус, Е.С. Рощупкин, С.В. Кукобко, С.В. Герасимов, Н.Ч. Дроб, М.Л. Трофимова

В современной научной литературе большое внимание уделяется сверхразделяюшим методам спектрального анализа, непосредственно методам линейного предсказания (ЛП) и модифицированным алгоритмам Кейпона (МАК). Разрешение таких методов зависит от номера элемента предсказания, оптимальное значение которого априори не известно. Возможный способ максимизации разрешения основывается на совокупном применении совокупности таких методов с разными номерами элементов предсказания. Целью статьи является анализ разрешения определения угловых координат точечных источников шумовых излучений (ИШИ) в радиолокаторах из ФАР на основе банка методов ЛП и МАК в реальных условиях параметрической априорной неопределенности и ограниченного объема выборки принятого сигнала. В статье описано формирование спектральных функиий методов ЛП и МАК в зависимости от номера элемента предсказания. Приведены спектральные функиии этих методов, построенные по точным корреляционным матрииам принимаемых колебаний. Показано, что в зависимости от мощности и углового расстояния источников спектральные функции имеют один или два максимума, определяющие потенциильное разрешение этих методов по критерию Релея. Приведены зависимости отношения сигнал - шум от относительного углового рассогласования между двумя равномощными ИШИ, при которых глубина провала обеспечивает раздельное наблюдение этих источников. Показано, что в условиях применения точно известной корреляционной матрицы более высокое разрешение обеспечивает выбор среднего предсказуемого элемента, чем крайнего. При матиматическом моделировании определялась зависимость вероятности правильного разделения ДШВ рассматриваемых методов от объема принятой выборки. Эти вероятности получаются путем статистической обработки результатов, полученных в серии из 500 испытаний. В каждом из них для определенной геометрии ФАР, количества, пространственного расположения и мощности ИШИ определялась истинная корреляиионная матрииа принятых сигналов на входе ФАР. Далее определялись корни этой матрииь, на основе одного из них формировалась выборка принятого сигнала определенного объема. С помощью этой выборки рассчитывалась оиенка корреляционной матрищы, последняя применялась для построения в определенных пределах сфектральных функиий методов ЛП и МАК с разными номерами. Для каждой из таких функиий определялось количество максимумов в соответствии с выбранным критерием. Полученные результаты статистически обрабатывались для определения вероятности правильного разделения каждого метода отдельно и в иелом для методов на основе этих методов. По результатам моделирования получены выводы: банк малого объема методов обеспечивает более высокое разрешение, чем каждого метода отдельно; увеличение объема банка методов обеспечивает дальнейшее увеличение разрешения пеленгатора; при равных условиях возможность правильного разделения как каждого метода, так и банка в иелом на их основе выше при увеличении интенсивности ИШИ; определяюший вклад в разрешение общего банка методов вносит группа методов МАК. Перспективным путем повышения эффективности пеленгачии точечных ИШИ в радиолокаторах с ФАР является комбинирование результатов работы различных методов спектрального анализа, 6 частности, методов ЛП и МАК с выбором различных номеров элементов предвидения, объединенных общим банком. С ростом количества методов в банке увеличивается разрешение радиолокатора. Реализачия такого банка методов спектрального анализа реализуется без значительных вычислительных затрат, поскольку для формирования такого банка применяются адаптивные решетчатые фильтры.

Ключевые слова: линейное предсказание, методы спектральной оченки, спектральный анализ, радиолокатор с фазированной антенной решеткой, точечные источники излучения. 